\title{
Methane Hydrate Formation, Storage and Dissociation Behavior in Unconsolidated Sediments in the Presence of Environment-friendly Promoters
}

Pandey, Jyoti Shanker; Daas, Yousef Jouljamal; von Solms, Nicolas

Publication date:

2020

Document Version

Peer reviewed version

Link back to DTU Orbit

Citation (APA):

Pandey, J. S. (Author), Daas, Y. J. (Author), \& von Solms, N. (Author). (2020). Methane Hydrate Formation, Storage and Dissociation Behavior in Unconsolidated Sediments in the Presence of Environment-friendly Promoters. 2D/3D (physical products)

\section{General rights}

Copyright and moral rights for the publications made accessible in the public portal are retained by the authors and/or other copyright owners and it is a condition of accessing publications that users recognise and abide by the legal requirements associated with these rights.

- Users may download and print one copy of any publication from the public portal for the purpose of private study or research.

- You may not further distribute the material or use it for any profit-making activity or commercial gain

- You may freely distribute the URL identifying the publication in the public portal 


\section{SPE Virtual Europec}

1-3 December 2020, Online

\section{Paper No. SPE-200532-MS}

Methane Hydrate Formation, Storage and Dissociation Behavior in Unconsolidated Sediments in the Presence of Environment-friendly Promoters

Jyoti Shanker Pandey, Yousef Jouljamal Daas, and Nicolas von Solms Technical University of Denmark 


\section{Presentation Outline}

- Introduction

- Objective

- Experimental setup

- Experimental results

- Conclusion 


\section{Introduction: Gas Hydrates \& Applications}

- What Are Gas Hydrates

- Ice-like, crystalline structures

- Common hydrate formers: methane, ethane, propane, carbon dioxide,

hydrogen sulfide, nitrogen, hydrogen

$$
\int_{\text {water }}^{20}+\underset{0}{\text { gas }}+\begin{aligned}
& \text { High } P \\
& \text { Low } T
\end{aligned}
$$
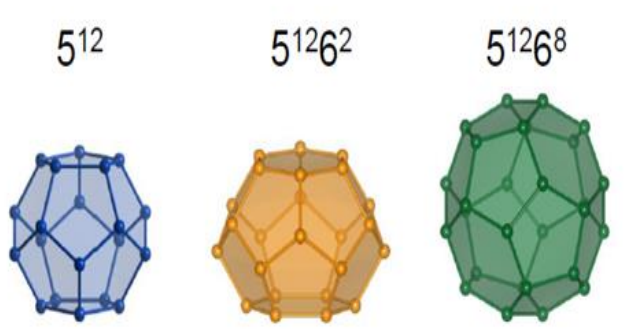

water cages
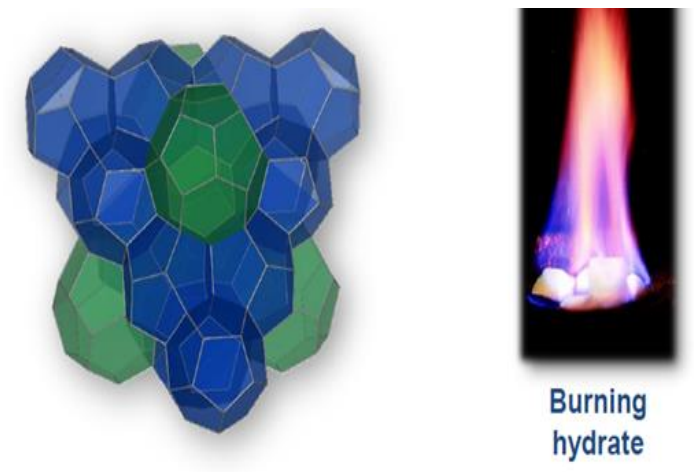

Gas storage capacity in hydrates

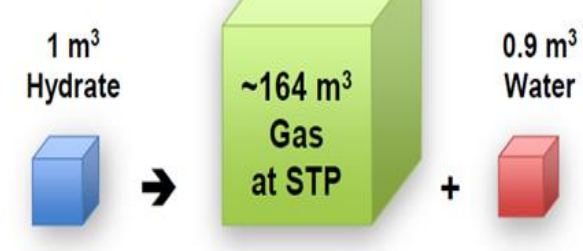

- Applications

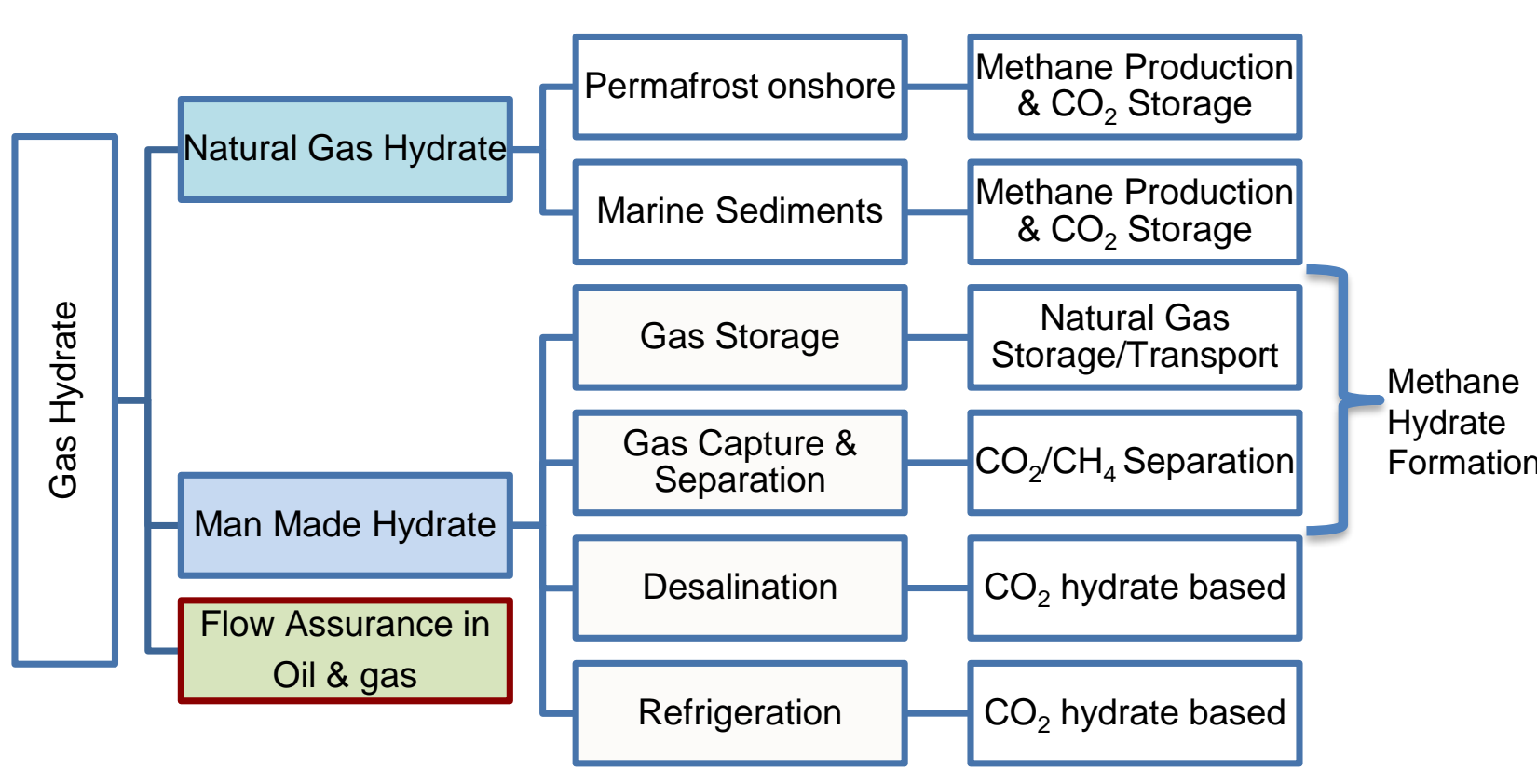




\section{Introduction: Role of Chemicals in Gas Hydrates}

Type of Chemicals

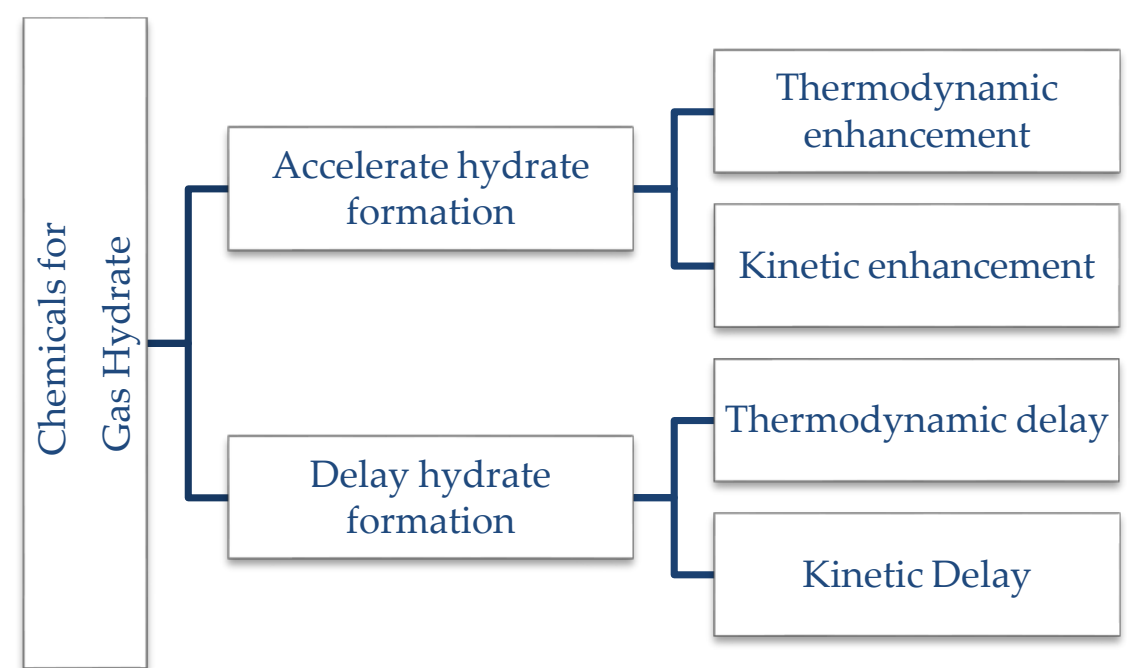

Chemicals can influence

- Surface tension

- Solubility

- Gas diffusion
Why Amino Acids ?
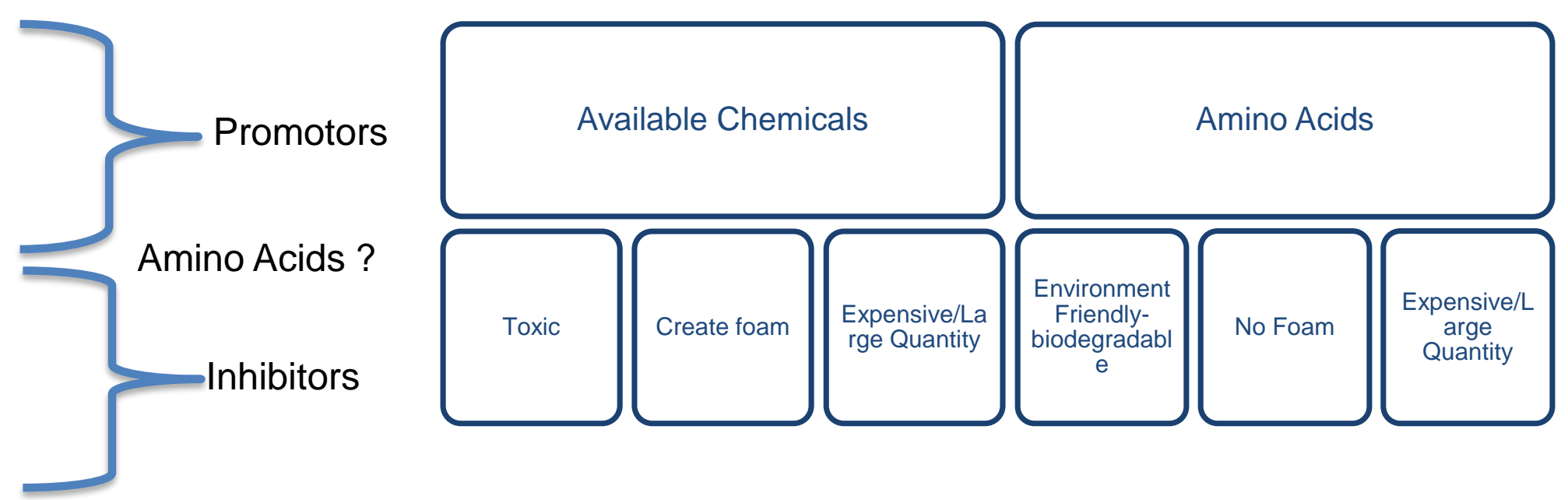


\section{Introduction Porous Media \& Promoter}

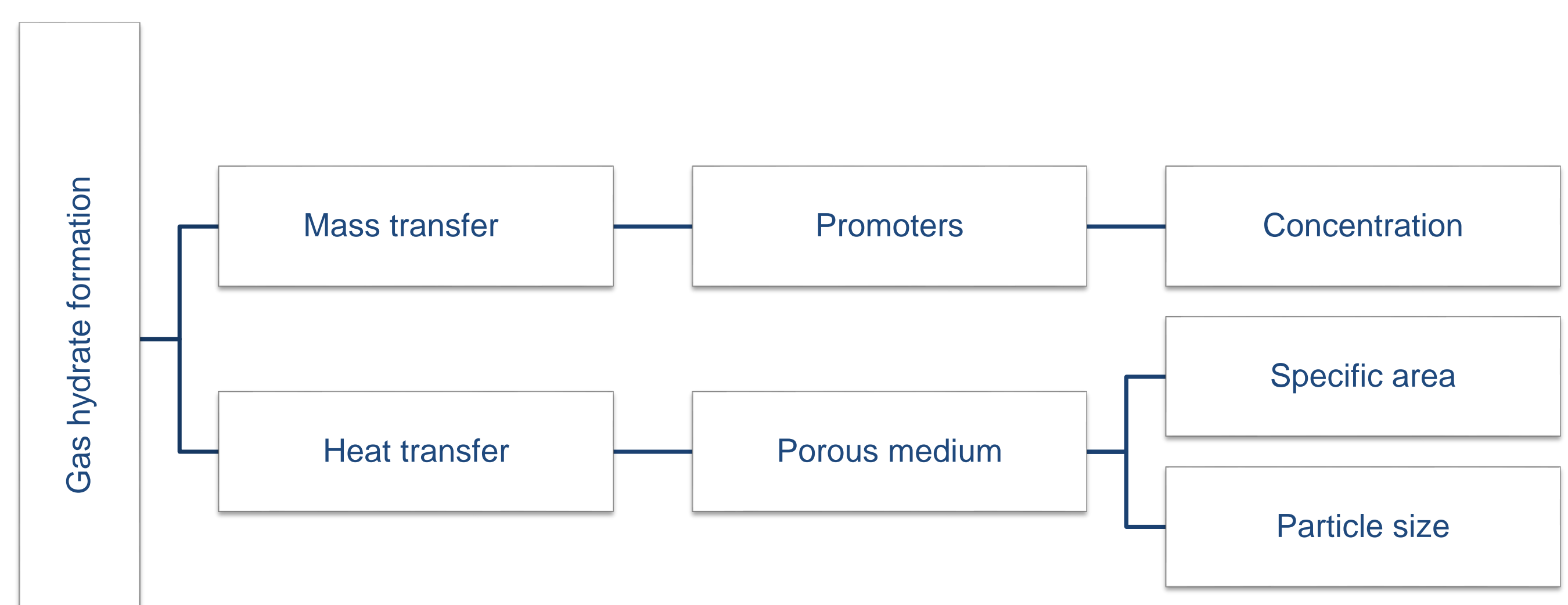




\section{Objective}

- To study the methane hydrate formation kinetics

- Change in particle size

- Presence of chemicals (Amino acids \& Surfactant)

- To study the dissociation kinetics 


\section{Experimental Setup}

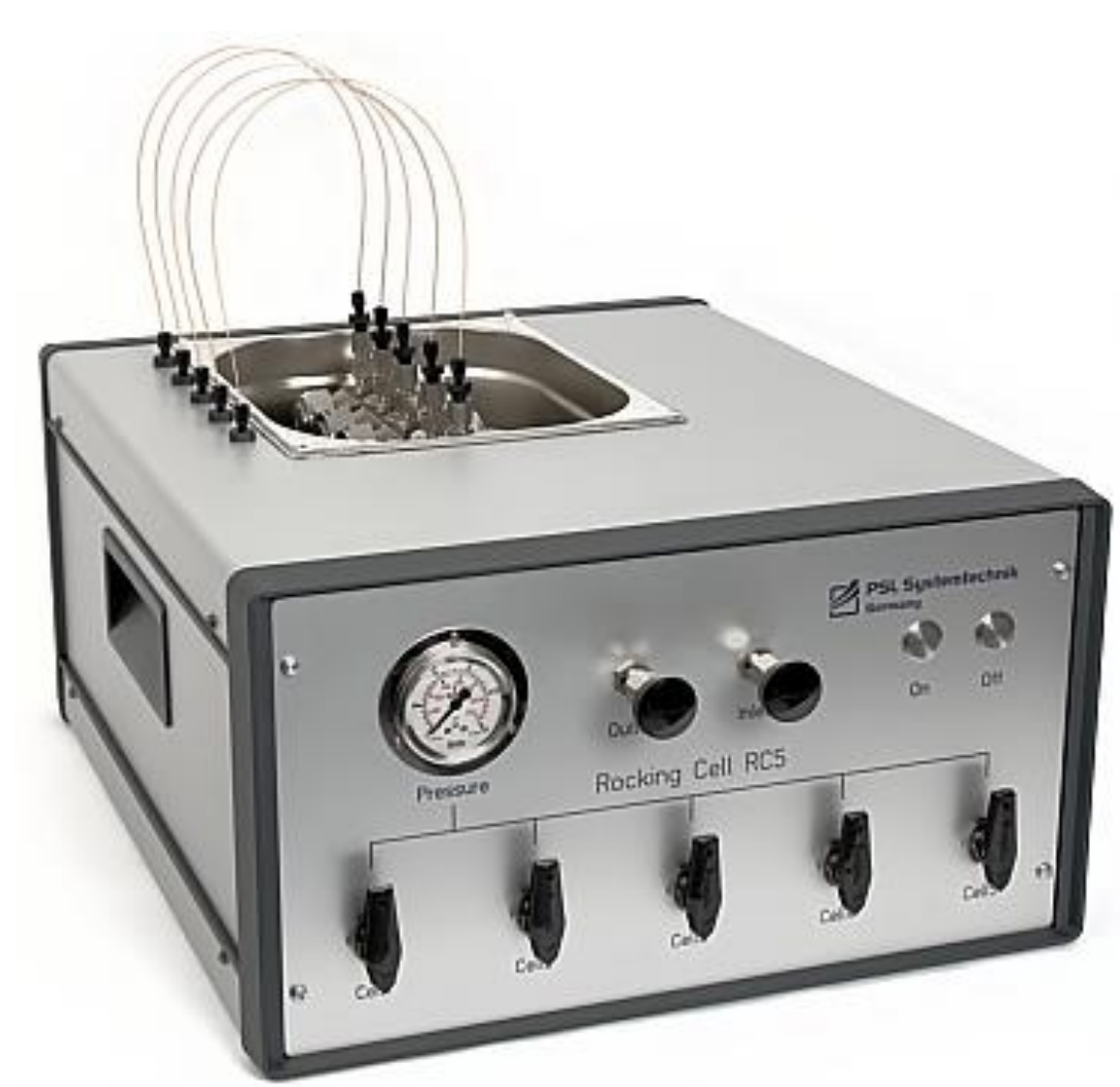

Rocking Cell (PSL Germany)

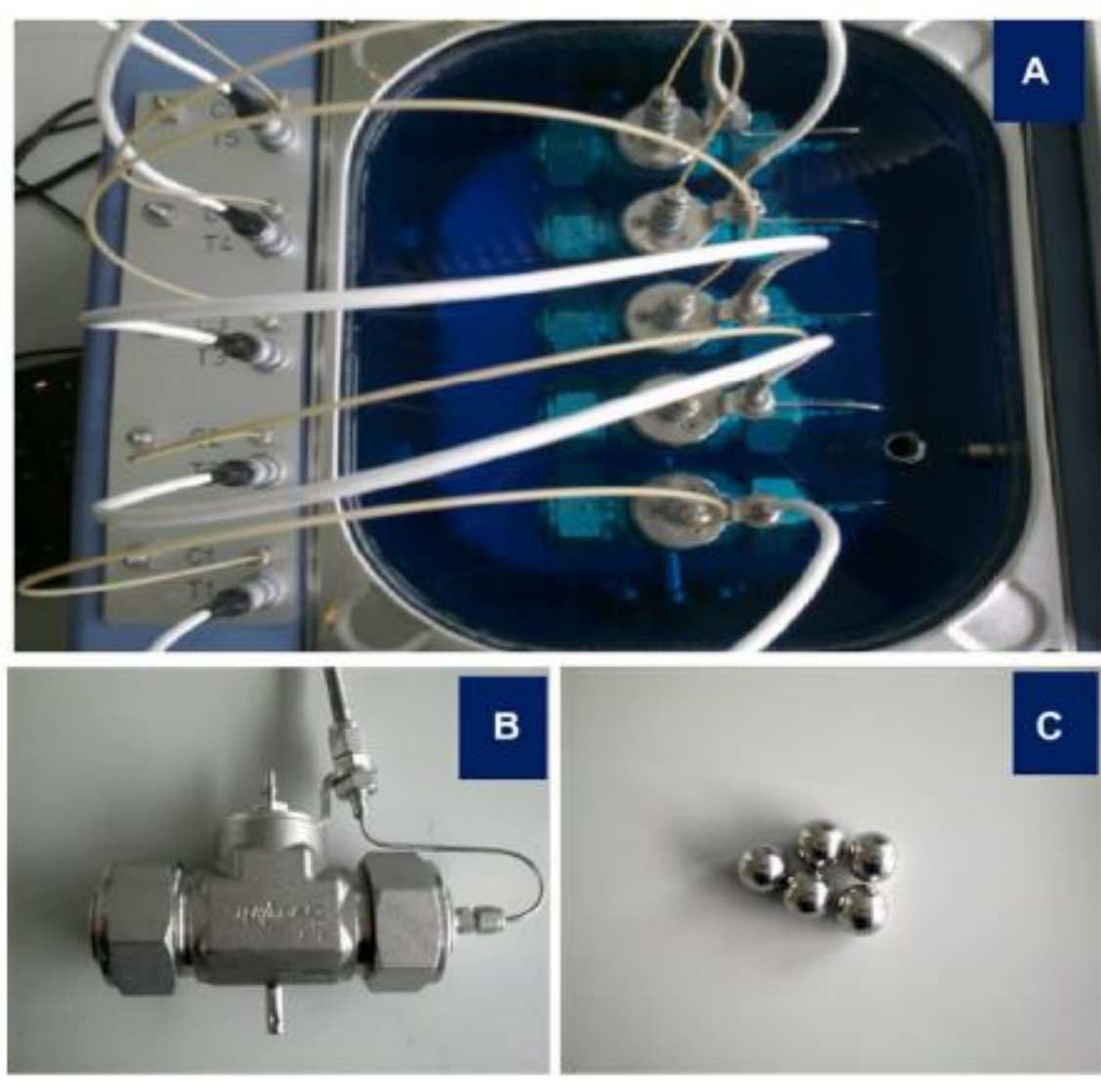

- A- Bathtub

- B- High Pressure Cell

- C- Rocking Balls
- Rocking Rate, Rocking Angle

- Volume

- Temperature Ramping, Constant Temperature 


\section{Experimental Setup: Method and Materials}

\begin{tabular}{|c|c|}
\hline Sand & $\begin{array}{l}\text { Silica Sand (4 Particle Sizes) } \\
\text { - } 46.4-245 \mu \mathrm{m} \\
\text { - } 160-630 \mu \mathrm{m} \\
\text { - } 480-1800 \mu \mathrm{m} \\
\text { - } 1400-5000 \mu \mathrm{m}\end{array}$ \\
\hline Amino acids (3000 ppm concentration) & $\begin{array}{l}\text { - L-valine } \\
\text { - L-methionine } \\
\text { - L-histidine }\end{array}$ \\
\hline Sodium dodecyl Sulfate (SDS) & $500-3000$ ppm $(500,1000,2000,3000$ ppm $)$ \\
\hline Experimental conditions & $100 \mathrm{bar}, 1^{\circ} \mathrm{C}$, Isothermal experiments \\
\hline Parameter calculated & $\begin{array}{l}\text { Induction time, gas uptake } \& \text { dissociation rate below } \\
0^{\circ} \mathrm{C}\end{array}$ \\
\hline
\end{tabular}




\section{Experimental Results- Formation Kinetics}

- Hydrate morphology

- Pore filling

- Grain coating

- Formation kinetic (Gas-liquid contact interface)

- Grain coating - Particle surface area

- Pore filling- Pore space

- Large particle size: higher pore space- Large gas-liquid contact area

- Small particle size : weak pore connectivity, barrier to mass transfer due to high capillary forces in smaller pore space

- $\mathrm{S}_{\mathrm{wi}}=35 \%$ change in grain coating to pore filling 


\section{Formation-Induction time}

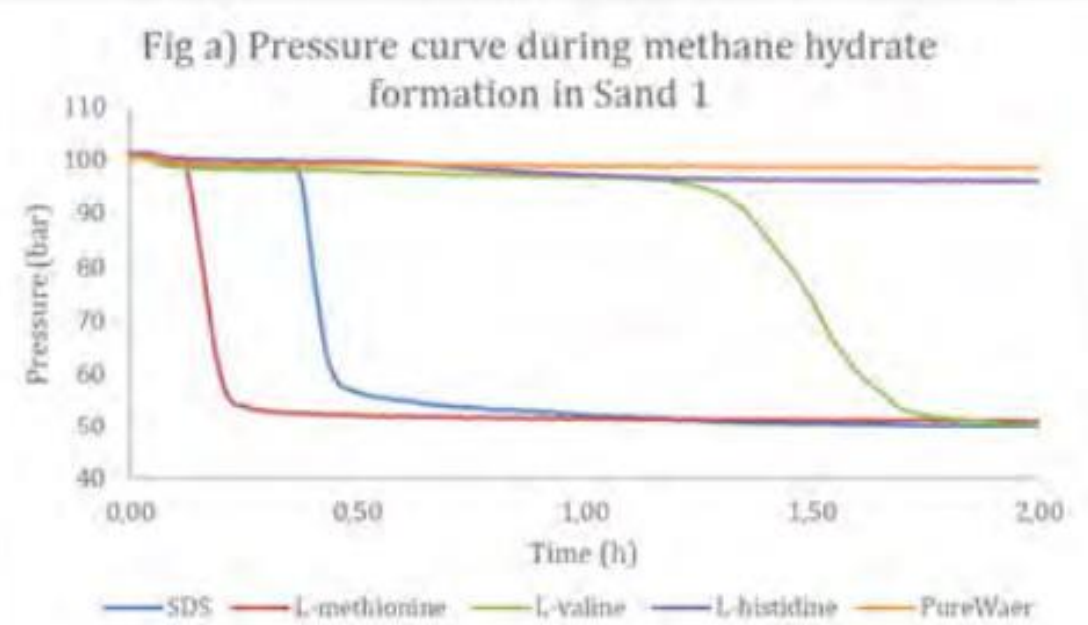

Fig b) Pressure curve during methane hydrate

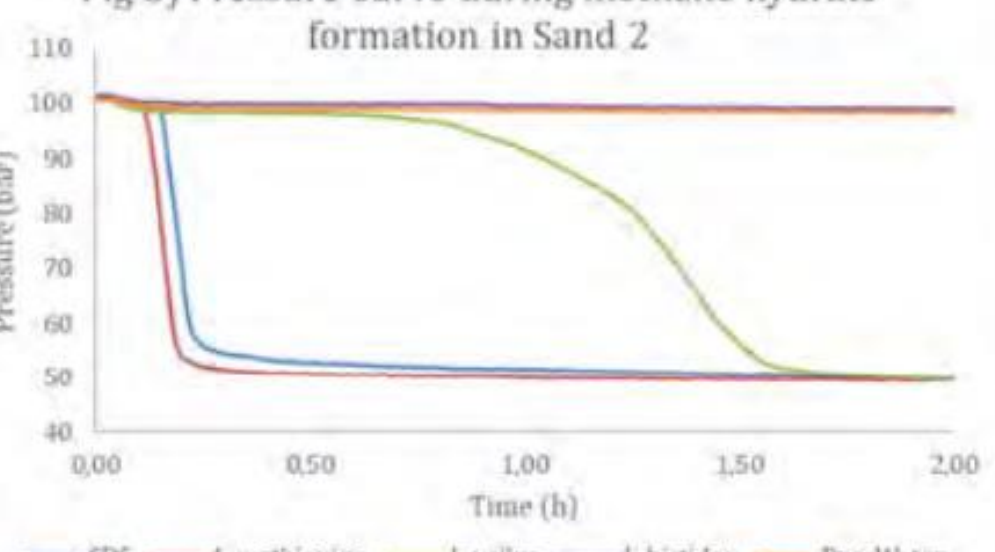

Fig c) Pressure curve during methane hydrate formation in Sand 3
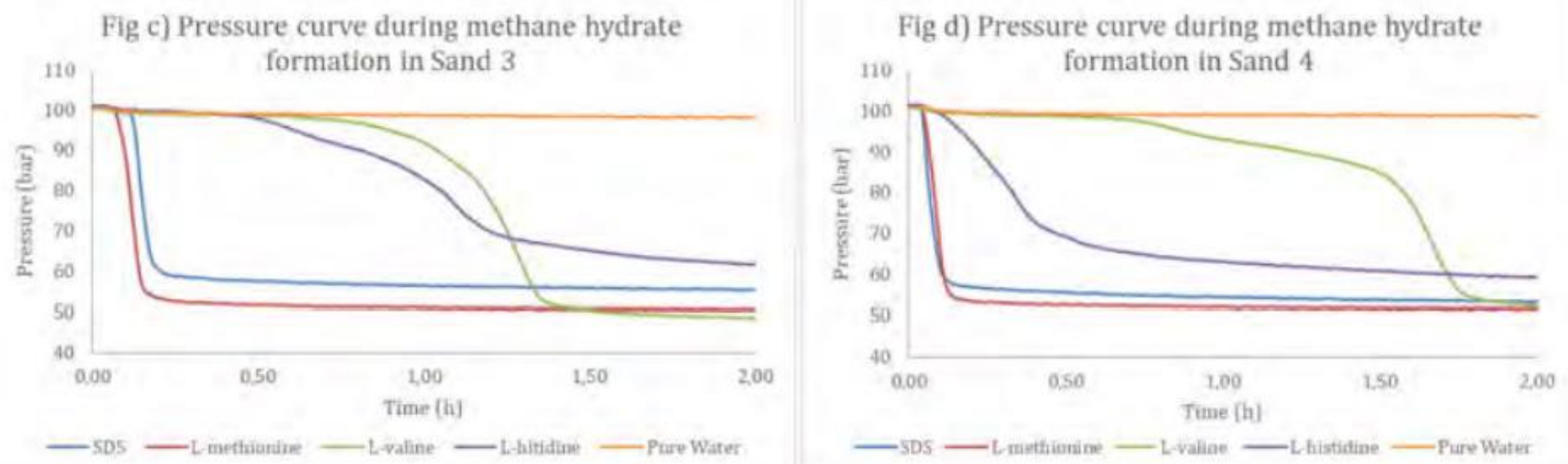

- Pressure variation during Isothermal experiments at $\mathrm{P}=$ 100 bar and $1{ }^{\circ} \mathrm{C}$

- for given sand particle size

- Induction time is lower for SDS / Hydrophobic amino acids for any given particle size 


\section{Formation-Induction time}

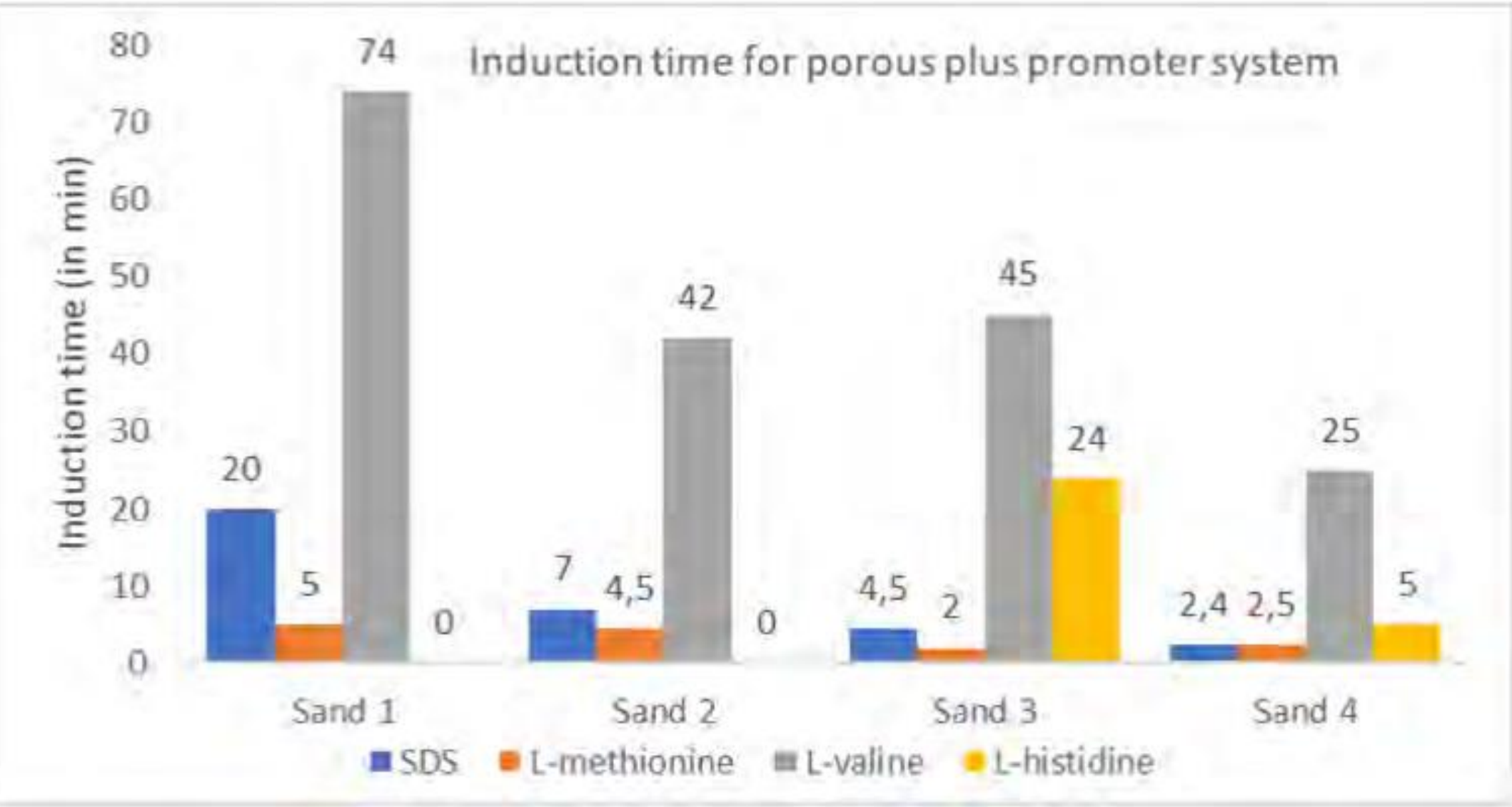

- Induction time is lower for SDS / Hydrophobic amino acids for any given particle size.

- Increase in particle size lead to decrease in induction time

- L methionine and SDS have similar induction time.

- Histidine could only formed hydrate at higher sand particle size.

- Enhanced driving force due to large gas-liquid interface 


\section{Gas Uptake}

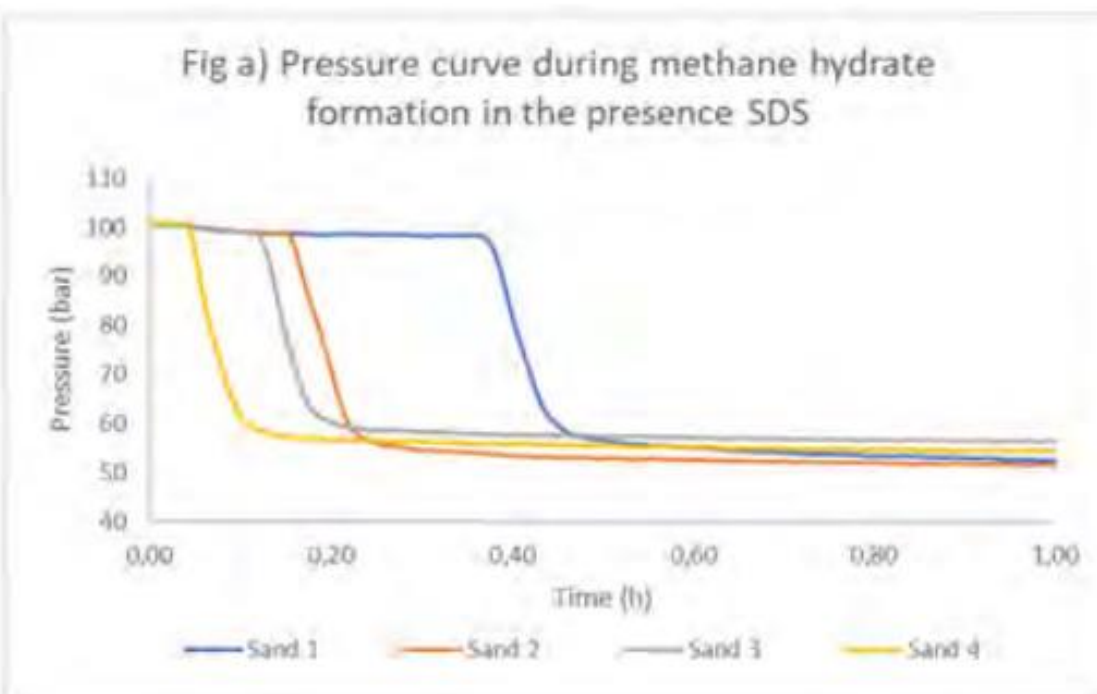

Fig c) Pressure Curve during methane hydrate formation in the presence of L-valine

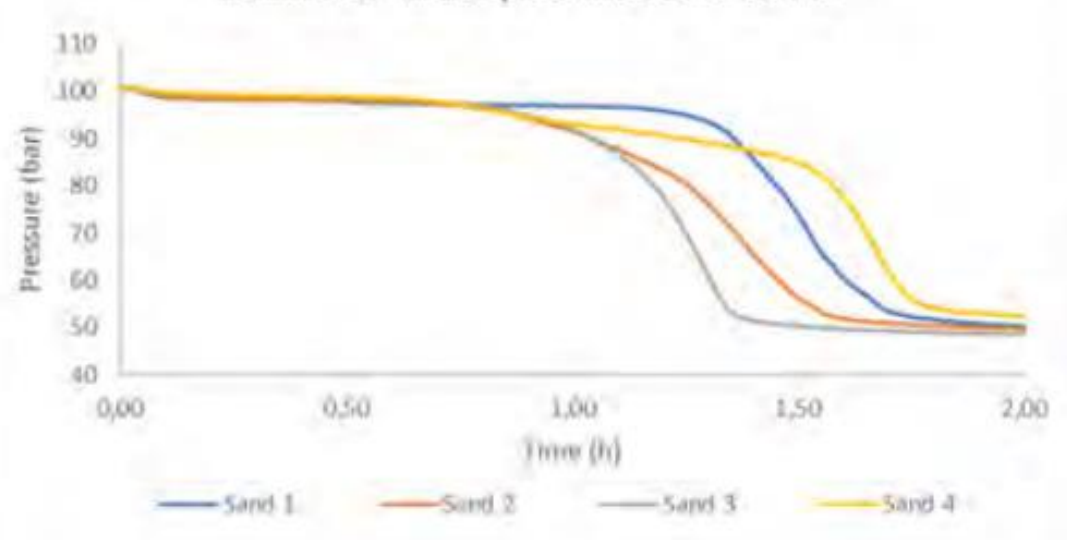

Fig b) Pressure curve during methane hydrate formation in the presence of L-methionine

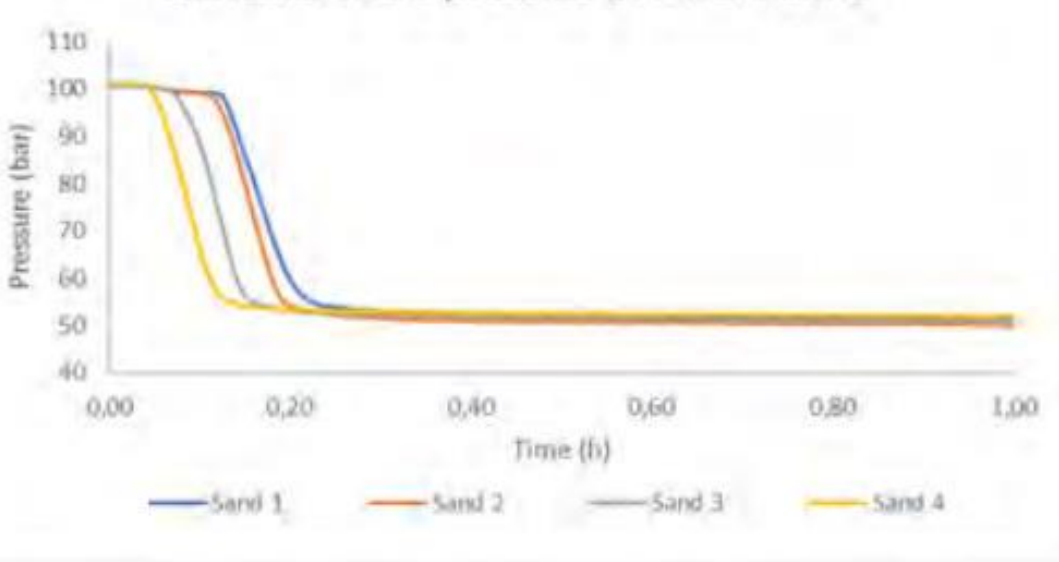

Fig d) Pressure curve during methane hydrate

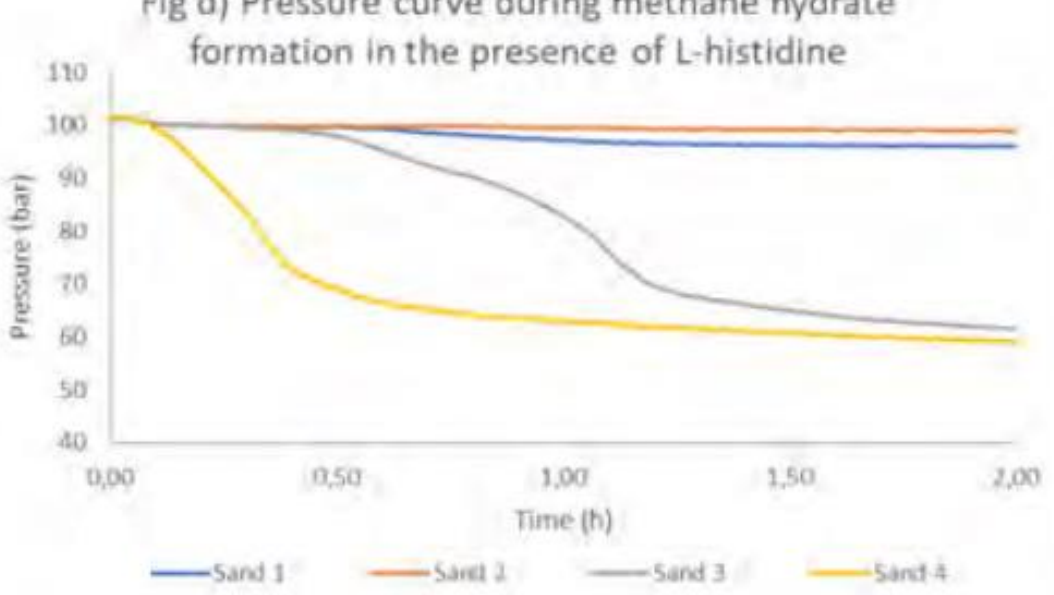

- Pressure variation during Isothermal experiments at $\mathrm{P}=100$ bar and $1^{\circ} \mathrm{C}$

- For low concentration (500 ppm), increase in particle size lead to decrease in gas uptake.

- At higher concentration, effect of sand particle size reduce and role of mass transfer increase

- For large particle size, change in concentration marginally affect gas uptake.

- For smaller particle size, change in concentration had dominating effect on gas uptake 


\section{Experimental Results-Dissociation}

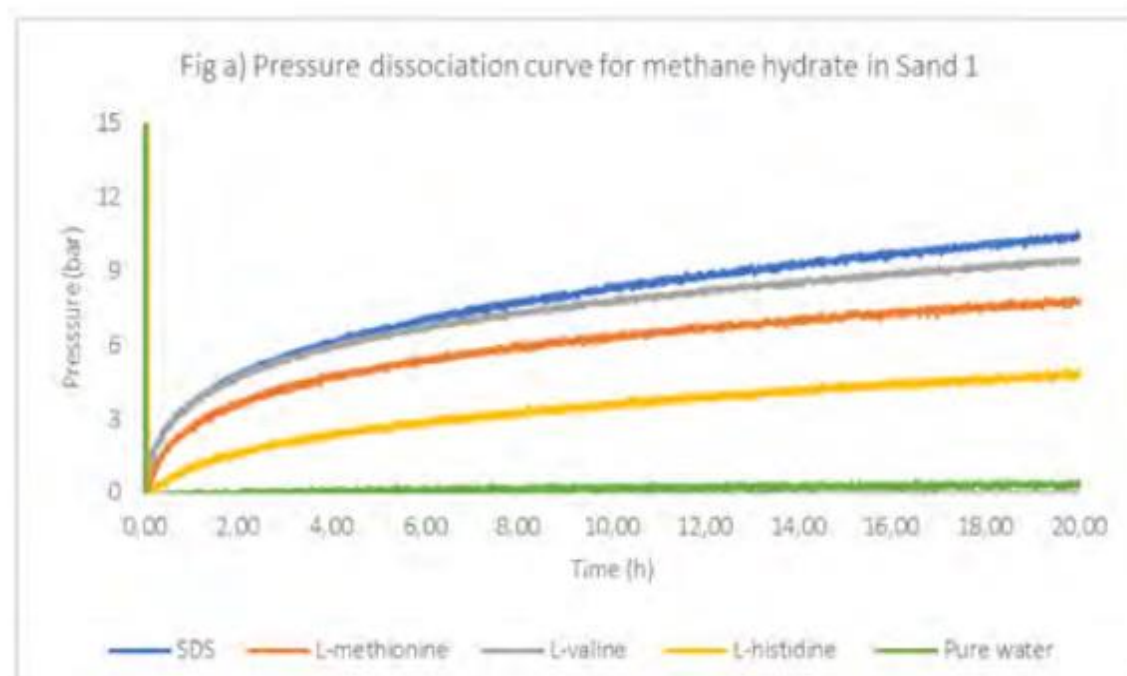

Fig b) Pressure dissociation curve for methane hydrate in Sand 2

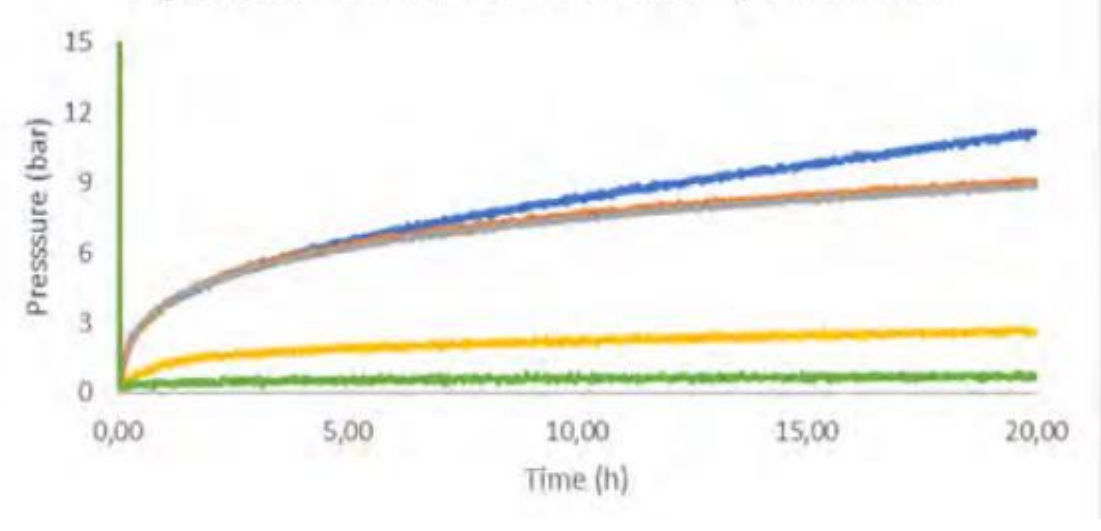

Fig c) Pressure dissociation curve for methane hydrate in sand 3

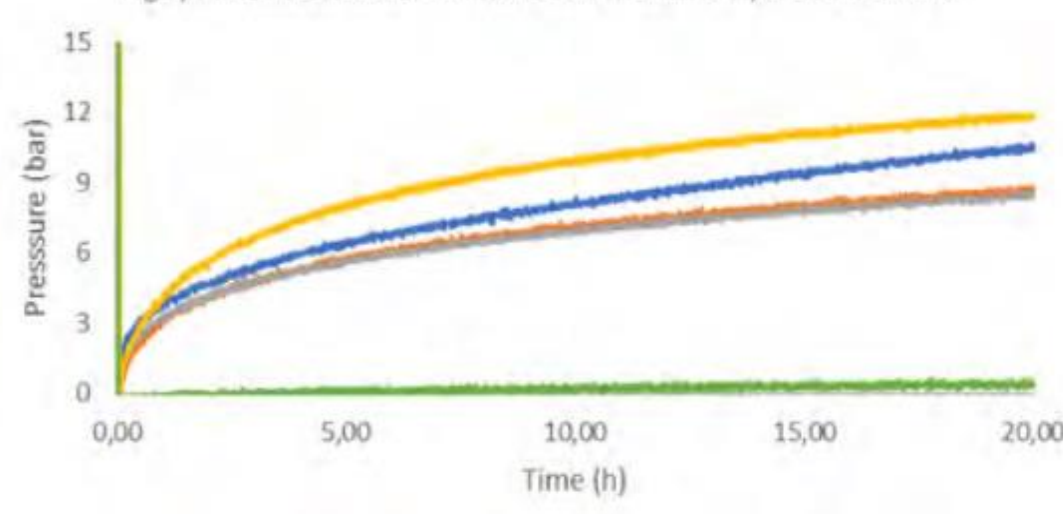

—SOS -Methionine - L-valine - i-histidine -Pure water

Fig d) Pressure dissociation curve for methane hydrate in sand 4

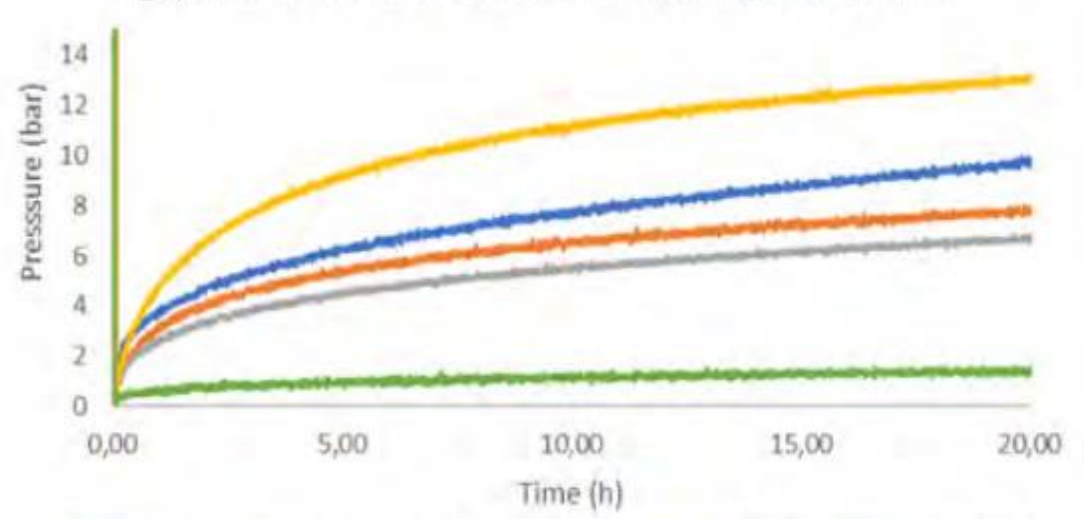

- $\quad$ Dissociation under $\mathrm{T}=266.7 \mathrm{~K}$ at starting pressure $\mathrm{P}=1$ bar.

- Self preservation of hydrates, Surrounded by ice sheet

- Dissociation rate is dependent on initial hydrate saturation.

- SDS/Hydrophobic amino acids dissociate faster

- SDS dissociate fastest for given sand particle while amino acids dissociated slower due to enhance hydrogen bonding 


\section{Conclusions}

- $\mathrm{S}_{\mathrm{wi}}$ controls formation kinetics.

- Low promoter concentration, particle size effect dominates the formation kinetics dominates

- Hydrophobic amino acids have similar kinetic behavior as SDS. Less deviation between amino acids and SDS at large particle size.

- Methane hydrate self preservation in the presence of hydrophobic amino acids enhanced. 


\section{Relevant Papers}

- Pandey, J. S., Daas, Y. J., \& von Solms, N. (2020). Screening of Amino Acids and Surfactant as Hydrate Promoter for $\mathrm{CO}_{2}$ Capture From Flue Gas. Processes, 8 , [124]. https://doi.org/10.3390/pr8010124

- Pandey, J. S., Jouljamal Daas, Y., \& Solms, N. V. (2019). Insights into Kinetics of Methane Hydrate Formation in the Presence of Surfactants. Processes, 7(9), [598]. https://doi.org/10.3390/pr7090598

- Pandey, J. S., Daas, Y. J., Karcz, A. P., \& Solms, N. V. (2020). Enhanced Hydrate-Based Geological CO2 Capture and Sequestration as a Mitigation Strategy to Address Climate Change. Energies, 13(21), https://doi.org/10.3390/en13215661 


\title{
ACKNOWLEDGEMENTS / THANK YOU / QUESTIONS
}

\author{
For further discussion \\ jyshp@kt.dtu.dk
}

